\title{
Piotr Niczyporuk, Bankierzy i operacje bankierskie w starożytnym Rzymie, Temida 2, Białystok 2013, ss. 302 Rzymska bankowość ukryta w meandrach języka łacińskiego
}

Językiem naukowych i uniwersalnych terminów w medycynie, biologii, fizyce i chemii jest język łaciński. Żyje on także w badaniach humanistycznych i ekonomiczno-prawniczych. Znaczeniełaciny jako języka nauki zrodziło zapotrzebowanie na różnego rodzaju słowniki, w tym medyczne, biologiczne i prawnicze. Ich autorzy musieli zmierzyć się z problemem przekładu terminów łacińskich na język polski, musieli odpowiedzieć sobie na pytanie: „Czy w trakcie przekładu można stosować zlatynizowane terminy techniczne, czy też $\mathrm{w}$ imię poprawności językowej lepiej z nich zrezygnować i używać wyłącznie polskich określeń, nawet gdyby to wymagało tworzenia neologizmów"1 ${ }^{1}$. Przed tym zadaniem stanął także Piotr Niczyporuk w swojej pracy Bankierzy i operacje bankierskie w starożytnym Rzymie opublikowanej w 2013 r. nakładem Wydawnictwa Stowarzyszenia Absolwentów Wydziału Prawa Uniwersytetu w Białymstoku - Temida $2^{2}$.

Piotr Niczyporuk, profesor Uniwersytetu w Białymstoku, od wielu lat swoje zainteresowania badawcze koncentruje wokół bankowości, zarówno w ujęciu historycznym, jak i współczesnym³ ${ }^{3}$. Sprawia to, że Autor

1 Pytanie to zadaje Janusz Sondel w artykule: Ze studiów nad rola $i$ miejscem łaciny prawniczej w kulturze europejskiej, „Krakowskie Studia z Historii Państwa i Prawa” 2014, 7, 1, s. 69-91.

2 http://temida2.uwb.edu.pl/pl/ [dostęp: 17 I 2018]. Wydawnictwo specjalizuje się w pracach prawniczych oraz z zakresu administracji, historii, filozofii, politologii. Ponadto wydaje naukowe czasopisma uniwersyteckie i publikacje okolicznościowe.

3 P. Niczyporuk, A. Talecka, Czynności bankowe w starożytnym Rzymie a wspótczesne polskie prawo bankowe, w: Pieniądz i banki - wspólnota dziejów (tezauryzacja, obieg pieniężny, bankowosść) - wspólnota dziejów. Białoruś - Litwa - Łotwa - Polska - Stowacja - Ukraina. Materiały z V Międzynarodowej Konferencji Numizmatycznej, red. K. Filipow, Warszawa 2002, s. 17-26; eidem, Babiloński kupiec - bankier (tamkarum) a wojna, w: Pieniądz i wojna. Białoruś - Litwa - Łotwa - Polska - Stowacja - Ukraina. Materiały z VI Międzynarodowej Konferencji Numizmatycznej, red. K. Filipow, Warszawa 2004, s. 15-23; eidem, Początki instytucji wspótczesnego prawa bankowego w starożytności, w: Podstawy materialne państwa. Zagadnienia prawno-historyczne, red. D. Bogacz, M. Tkaczuk, Szczecin 2006, s. 337-352; eidem, Nummularii jako strażnicy jakości monety w starożytnym Rzymie, w: Psucie pieniadza w Europie Środkowo-Wschodniej od antyku po 
z charakterystyczną dla siebie sprawnością porusza się w gąszczu terminologii bankowej. Ponadto czynnie wykonuje zawód radcy prawnego, co wpływa na jego postrzeganie prawa oraz widoczne jest $w$ ujęciu podejmowanej przez niego tematyki. W swoich pracach $z$ dziedziny prawa rzymskiego używa współczesnych pojęć i koncepcji, aktualizując "tradycyjne" ujęcie problematyki starożytnej. Zajmuje się także rzymskim prawem familijnym oraz sytuacją prawną dziecka poczętego, a nienarodzonego. Tematykom tym poświęcił wiele prac, zarówno w formie monografii, artykułów, jak i podręczników oraz skryptów ${ }^{4}$. Z kolei w recenzowanej

czasy wspótczesne. Białoruś - Litwa - Łotwa - Polska - Stowacja - Ukraina. Materiały z VII Międzynarodowej Konferencji Numizmatycznej, red. K. Filipow, Warszawa 2006, s. 23-30; eidem, Bank jako instytucja zaufania publicznego, w: Ekonomiczne aspekty państwa demokratycznego, red. S. Oliwniak, Białystok 2007, s. 73-88; eidem, Kredyt bankowy dla jednostek samorzadu terytorialnego w świetle regulacji prawnych, w: Finansowanie gminnego samorzadu terytorialnego, red. D.A. Hałaburda, Białystok 2008, s. 137-153; eidem, Aukcyjna sprzedaż majątków jako jedna z form działalności bankierskiej w starożytnym Rzymie, w: Pieniądz - kapitat - praca-wspólne dziedzictwo Europy. Białoruś - Litwa - Łotwa - Polska - Rosja - Stowacja - Ukraina. Materiały z VIII Międzynarodowej Konferencji Numizmatycznej, red. K. Filipow Warszawa 2008, s. 21-27; eidem, Rzymska antyczna bankowość wspólnym dziedzictwem Europy, w: Pieniadz - symbol - władza - wojna wspólne dziedzictwo Europy, Białoruś - Estonia - Litwa - Łotwa - Polska - Rosja - Rumunia - Stowacja-Ukraina. Studia i materiały, red. K. Filipow, Augustów-Warszawa 2010, s. 27-41; P. Niczyporuk, Mensarii, Bankers Acting for Public and Private Benefit , "Studies in Logic, Grammar and Rhetoric" 2011, 24 (37), s. 105-115; idem, Aukcyjna sprzedaż majątków z udziałem bankierów w starożytnym Rzymie, w: Z zagadnień prawa rolnego, cywilnego i samorzadu terytorialnego. Ksiega jubileuszowa profesora Stanisława Prutisa, red. J. Bieluk, A. Doliwa, A. Malarewicz-Jakubów, T. Mróz, Białystok 2012, s. 596-605; idem, Mensarii - какбанкиры, „Miscellanea Historico-Iuridica" 2012, 11, s. 29-40; idem, Operacje wykonywane przez bankierów rzymskich (argentarii), „Krytyka Prawa” 2013, 5, s. 481-506; idem, Bankierzy publiczni w źródłach prawa rzymskiego, "Zeszyty Prawnicze” 2014, 14.1, s. 113-131; idem, Bankierzy publiczni w starożytnym Rzymie, „Zeszyty Naukowe Uniwersytetu Rzeszowskiego. Seria Prawnicza” 2014, 82, Prawo 14, s. 145-161; idem, Bankierzy u Plauta, "Zeszyty Naukowe Uniwersytetu Rzeszowskiego, Seria Prawnicza" 2014, 82, Prawo 14, s. 162-173; P. Niczyporuk, A. Talecka, Nummularii, государственные и частные банкиры в древнем Риме, „Miscellanea Historico-Iuridica” 2013, 12, s. 57-74; eidem, Bankowość. System bankowy i usługi, Białystok 2004; eidem, Банковская система и банковское регулирование в Европейском Союзе, Белосток 2010 ; eidem, Bankowość Unii Europejskiej. Podstawowe zagadnienia, Białystok 2010; eidem, Bankowość. Podstawowe zagadnienia, Białystok 2011.

4 P. Niczyporuk, Tempus lugendi, w: Miscellanea Historico-Iuridica Bialostocensia, Białystok 1995, s. 35-45; idem, Żałoba w prawie rzymskim, w: Prawo a dzieje państwa i ustroju, Białystok 1996, s. 57-77; idem, Warunek pozostania we wdowieństwie w prawie rzymskim, w: Przez tysiaclecia: państwo - prawo - jednostka. Materiaty z ogólnopolskiej konferencji historyków prawa. Ustroń 17-20 września 2000 r., t. 3, red. A. Lityński, M. Mikołajczyk, s. 199-214; idem, Powtórne matżeństwo wdowy w okresie tempus lugendi w epoce archaicznej prawa rzymskiego, w: Honeste vivere, Księga pamiatkowa ku czci Profesora Władystawa Bojarskiego, red. A. Sokala, E. Gajda, Toruń 2001, s. 139-149; idem, Legaty na rzecz wdowy w prawie rzymskim, „Miscellanea Historico-Iuridica" 2003, 1, s. 9-35; idem, Nasciturus - postumus: римская юордическая терминология, применяемая для определения зачатого мляденияа, \{Nasciturus - postu- 
publikacji Autor podjął trud analizy terminów używanych na określenie osób zajmujących się działalnością bankową w starożytnym Rzymie ${ }^{5}$.

Bankierzy i operacje bankierskie... składa się ze Wstępu (s. 15-25), trzech rozdziałów: Terminologia używana na określenie osób zajmujacych się działalnościa bankowa (s. 28-74); Operacje bankierów rzymskich (s. 75-145); Forma prowadzenia działalności bankierskiej i jej ewidencja (s. 146-197) oraz Zakończenia (s. 198205). Praca wzbogacona jest o indeks źródeł: Źródła prawne (s. 207-210) Źródła literackie (s. 210-216) oraz Źródła epigraficzne i papirologiczne (s. 216-217). Wypis użytych wszystkich źródeł wraz z numeracją stron ich przytoczenia jest niezwykle pomocny. Piotr Niczyporuk dokonał bardzo szczegółowego podziału, uwzględniając zarówno źródła zawarte w tekście zasadniczym pracy, jak i w przypisach. Te drugie oznaczył, stosując nawiasy kwadratowe. Ponadto w nawiasach okragłych Autor bardzo konsekwentnie podaje edycję wszystkich przytoczonych w niniejszej monografii źródeł. Spis treści umieszczony na początku (s. 5-7) jest przejrzysty i sporządzony bez zbędnej szczegółowości. Autor podzielił rozdziały na podrozdziały, te zaś na mniejsze jednostki, co znacząco systematyzuje i tym samym ułatwia lekturę. Pewnej korekty wymagają podane w nim strony - Wstęp rozpoczyna się na stronie 13, a nie 15; Rozdział I zaś na 27, a nie 28, natomiast Rozdział II na 75, a nie 77. Ponadto zauważalny jest brak uwzględnienia Źródeł epigraficznych i papirologicznych rozpoczynających się na stronie 216 oraz streszczenia w języku łacińskim (s. 294). Bibliografia została podzielona na dwie części: Wydawnictwa źródłowe, słownikowe i encyklopedyczne (s. 219-223) oraz Literatura (s. 223-279). Podział ten może być jednak zaskakujący, bowiem umieszczenie enumeratywnego wypisu wydawnictw źródłowych wraz ze słownikami i encyklopediami wydaje się mało zrozumiałe. Moim zdaniem

mus: rzymska terminologia stosowana wobec dziecka poczętego\}, „Ius Antiquum” 2004, 2, 14, s. 116-131; idem, Sankcje nałożone na wdowe nie przestrzegajaca zakazu powtórnego matżeństwa w okresie tempus lugendi, w: Contra leges et bonos mores. Przestępstwa obyczajowe w starożytnej Grecji i Rzymie, red. H. Kowalski, M. Kuryłowicz, Lublin 2005, s. 263-273; P. Niczyporuk, A. Talecka, Prawne aspekty czasu trwania ciaży w starożytnym Rzymie , w: Kobieta - Etyka Ekonomia, red. E. Ozorowski, R.Cz. Horodeński, Białystok 2009, s. 107-125; P. Niczyporuk, Rzymskie regulacje prawne zwiazane z ochrona dziecka poczętego, "Miscellanea Historico-Iuridica" 2009, 8, s. 27-40; idem, Określenia stosowane w źródłach prawa rzymskiego wobec dziecka poczętego, a jeszcze nieurodzonego, w: O prawie i jego dziejach księgi dwie, red. P. Fiedorczyk, M. Mikołajczyk, Białystok-Katowice 2010, Księga I, s. 81-92; idem, Stwierdzenie ciaży (inspectio ventris) jako środek ochrony interesów dziecka poczętego w prawie rzymskim, „Miscellanea Historico-Iuridica" 2010, 9, s. 29-40; idem, Rozważania Wolfganga Waldsteina o dziecku poczetym, w: Interes prywatny a interes publiczny w prawie rzymskim, red. B. Sitka, K. Naumowicz, K. Zaworska, Olsztyn 2012, s. 217-229.

5 Jak sam Autor wskazuje, w 2002 r. ukazała się monografia Aldo Petrucciego, Profi li giuridici delle attività e dell'organizzazione delle banche romane. Jest ona jednak tylko próbą przedstawienia aktywności i form organizacyjnych bankowości rzymskiej. 
wydawnictwa źródłowe oraz słowniki i encyklopedie należałoby zamieścić oddzielnie. Trudno bowiem wskazać dla nich element wspólny. Monografia zakończona jest obszernymi streszczeniami - dwoma w językach kongresowych - języku angielskim (s. 281-287) i języku włoskim (s. 289-294) oraz bardzo imponujące w języku łacińskim (s. 294-302).

Piotr Niczyporuk w swojej pracy stara się odpowiedzieć na następujące pytania: „Czy istnienie wielu terminów używanych na określenie osób zajmujących się działalnością bankową było oznaką swego rodzaju specjalizacji wśród tej grupy zawodowej?” (s. 16) oraz „Czy w związku z nazewnictwem podmiotów podejmujących się operacji bankierskich można im przypisać wykonywanie konkretnych czynności charakterystycznych tylko dla nich?" (s. 16). Trud ten badacz podjął, wychodząc od badań językoznawczych, a dokładnie etymologicznych, którym poświęcił rozdział pierwszy (Terminologia używana na określenie osób zajmujacych się działalnościa bankowa). Autor w bardzo staranny sposób zapoznaje czytelnika z dziewięcioma [sic!] określeniami osób zajmujących się działalnością bankierska, takimi jak: trapezitae, argentarii, mensarii, mensularii, numullarii, coactor, coactores argentarii, stipulatores argentarii oraz collectarii. Prawnicy rzymscy bowiem, co zostało przez niego wykazane, posługiwali się w tej dziedzinie rozbudowaną terminologią. Konfrontacja zgromadzonych przez P. Niczyporuka pojęć na określenie bankierów w zestawieniu z Słownikiem łacińsko-polskim pod redakcją Mariana Plezi ${ }^{6}$ wskazuje na bardzo rzetelne studium materiału źródłowego i wzbogacenie języka polskiego o definicje, dotąd nie znane w takim stopniu w polskiej literaturze przedmiotu. W taki sposób Autor wzbogacił słownik łacińsko-polski o znaczenie trapezita, powołując się, podobnie jak autor hasła w słowniku pod redakcją M. Plezi, na dzieła Plauta, jednak w znacznie szerszym zasięgu - zarówno co do liczby cytowań w jego dziełach, jak i interpretacji. Należy bowiem pamiętać, że trapezita to pojęcie pochodzenia greckiego, które zostało zanotowane przez komediopisarza i tłumacza na język łaciński komedii greckich i dostosowane do rzymskich realiów. Ponadto termin ten wzmiankuja, o czym milczą słowniki, konstytucje cesarzy Teodozjusza i Walentyniana z 436 r. n.e. Zamiennie, jak twierdzi Autor, termin ten używany jest przez Plauta z terminem łacińskim argentarius. Najstarszym źródłem, które na to wskazuje, jest Ab Urbe condita Tytusa Liwiusza. Ponadto argentarius występuje zarówno w źródłach prawniczych u Gajusza, jak i biograficznych Swetoniusza.

Kolejny termin mensarius został zdefiniowany w słownikach jako urzędnik zarządzający kasą państwową lub jako bankier, lichwiarz. Autor hasła w słowniku nie wskazuje jednak na możliwość jego identyfikacji z łaciń-

6 Słownik łacińsko-polski, t. I-V, red. M. Plezia, Warszawa 2007. 
skim odpowiednikiem greckiego trapezites. Jest to istotne przy określeniu swego rodzaju specjalizacji wśród tej grupy zawodowej. P. Niczyporuk, definiując mensularius, stanowczo krytykuje utożsamianie tego terminu z bankierem, lichwiarzem czy wekslarzem, co ma miejsce w różnych leksykonach oraz słownikach. Termin ten, jak podkreśla Autor, oznacza prywatnego bankiera, który prowadził swoje operacje na Forum. Wzmiankują o nich zarówno źródła prawnicze - Digesta, jak i literackie - Seneka, Swetoniusz. Nummularius zaś to nie tylko wekslarz, bankier, urzędnik kontrolujący kruszec przed wybiciem pieniędzy, ale przede wszystkim właściciel małego banku, początkowo służącego do wymiany pieniędzy. Z kolei coactor to nie tylko osoba mająca związek z poborcą podatków, celnikiem, komornikiem, ale także ta, która zajmowała się niektórymi czynnościami bankowymi, co znajduje potwierdzenie w rzymskiej literaturze nieprawniczej, u Katona oraz w inskrypcjach nagrobnych. Wszystkie te informacje przemilczały słowniki łacińsko-polskie. Autor dodaje także, że instytucje rzymskie znały ponadto coactores argentarii, którzy pojawili się w I w. p.n.e., a ich działalność była związana z aukcjami; oraz stipulatores argentarii i collectarii, którzy zajmowali się wymianą pieniędzy.

Wypada podkreślić, że jest to pierwsza praca w języku polskim tak szczegółowo ukazująca owo zagadnienie. Dzięki refleksji natury etymologicznej P. Niczyporuk zbudował swego rodzaju „most kulturowy” pomiędzy światem greckim i rzymskim. Wykazał bowiem, że w niejednym wypadku terminologia łacińska wywodzi się z języka greckiego. Tym samym dowiódł, że rzymska terminologia bankowa nie powstała w próżni. Innymi słowy, dzięki monografii Bankierzy i operacje bankierskie... możemy wzbogacić swoją wiedzę z zakresu fachowej terminologii łacińskiej.

W trakcie przekładu pojęć z tekstów źródłowych Autor zdecydował się nie tworzyć neologizmów, tylko zastosować zlatynizowane terminy techniczne. Co istotne, P. Niczyporuk oparł refleksje językoznawcze na źródłach jurydycznych oraz literackich. Jak sam podaje: „Bazę źródłową dla przeprowadzonych badań tworzą głównie teksty jurydyczne, od fragmentów ustawy XII tablic począwszy, poprzez edykt pretorski oraz jego rekonstrukcję sporządzoną przez O. Lenela, zachowane dzięki umieszczeniu ich przez kompilatorów w Digestach, fragmenty pism klasycznych jurystów rzymskich, przekazane opracowania i zbiory poklasyczne, po kodyfikację justyniańską (VI w.)." (s. 19). Trzeba podkreślić, że publikacja charakteryzuje się bardzo rzetelną analizą źródeł, jednakże zauważalny jest brak ich polskich tłumaczeń, dzięki którym praca o tak dużym potencjale znalazłaby szersze zainteresowanie, nie tylko wśród specjalistów z dziedziny prawa rzymskiego czy historii starożytnej. Musimy bowiem wziąć pod uwagę znaczenie kultury bankowości 
we współczesnym świecie i starać się popularyzować badania z szeroko rozumianej humanistyki.

W rozdziale drugim (Operacje bankierów rzymskich) Piotr Niczyporuk w płynny sposób przechodzi do omówienia pięciu rodzajów operacji bankierów rzymskich, tj.: działalności depozytowej, działalności pożyczkowej, pośrednictwa w sprzedaży aukcyjnej majątków, sprawdzania jakości oraz wymiany monet, a także windykacji długów klientów, kontynuuje rozważania podjęte w rozdziale pierwszym. Dostosowuje rodzaj działalności do konkretnych bankierów, uwzględniając przy tym zmiany zachodzące w przestrzeni czasowej. Tym samym dwa pierwsze rozdziały stanowią integralną część, zazębiając się zarówno tematycznie, jak i metodologicznie. Działalności depozytowej, depositum regulare i depositum irregulare, został poświęcony, jak podaje Autor, trzeci tytuł szesnastej księgi Digestów, zatytułowanej Depositi vel contra-O depozycie i wyptacie (s. 77). Ponadto wspominają o niej Konstytucje Cesarskie oraz Plaut - jak widać bardzo cenne źródło wiedzy z dziedziny tematyki bankierskiej. Piotr Niczyporuk, opisując czynności związane z działalnością bankowa identyfikuje je z podmiotami, które za nie odpowiadały. I tak numullarii - za deposito regulare, zaś mensularii - za deposito irregulare. Wspomina także o receptum argentarii, które zastrzeżone było dla argentarii (o czym świadczy nazwa), później zaś zostało rozszerzone na nummularii. Kolejną formą działalności bankierskiej, bardzo lukratywna, były pożyczki - nexum oraz mutuum. Informację o nich znajdziemy zarówno w pismach jurystów rzymskich (zob. Digesta), jak i w źródłach literackich - Plauta czy Swetoniusza. Następnie, przechodząc od kontraktów werbalnych (stypulacja), Autor ukazuje moment boomu kontraktu literalnego (chirographum - list kredytowy). Czynnością wymiany monet, jak podkreśla, zajmowali się zarówno nummularii, argentarii, mensularii, jak i prawdopodobnie coactores argentarii. Ci ostatni, którzy byli „,swego rodzaju pośrednikami finansowymi” (s. 145), windykowali wierzytelności $\mathrm{w}$ imieniu i na rzecz klienta. $\mathrm{W}$ opisanych $\mathrm{w}$ rozdziale drugim wszystkich czynnościach prawnych szczególne miejsce zajmują podmioty - konkretni bankierzy, którzy się nimi trudnili. Autor kontynuuje zatem rozważania z rozdziału pierwszego, poszerzając je o opis i szczegółową interpretację językową omówionych pojęć. Rozdział pierwszy pisany jest bowiem z punktu widzenia właściwości podmiotu sprawującego funkcję bankiera, natomiast drugi według właściwości przedmiotu - czynności bankierskich.

Kontynuując swoje badania nad bankowością rzymska, Piotr Niczyporuk w płynny sposób przechodzi do rozdziału trzeciego (Forma prowadzenia działalności bankierskiej i jej ewidencja), opisując właściwości form, w których prowadzono działalność bankierską. Na pierwszym miejscu, ponownie w kontekście podmiotów, omawia miejsca takiej działalności. Wskazuje na ich różnorodność, bowiem były to grunty publiczne - zarówno fora, jak 
i miejsca w pobliżu świątyń, które przyciągały nie tylko wiernych, ale także potencjalnych kontrahentów, chcących wymienić lub rozmienić monety. Wskazując na początki rozwoju działalności bankierskiej, Autor wyróżnia moment powstania pojęć mensae argentariae oraz mensae nummularia. Jak twierdzi „Termin mensa niewątpliwie wiązał się z ewidencją prowadzonej działalności i odnosił się do tych bankierów, którzy w sposób profesjonalny i permanentny, a nie dorywczy podejmowali swoje operacje" (s. 195). W rozdziale trzecim Piotr Niczyporuk rozróżnia osoby prowadzące osobiście operacje bankierskie, od tych, które w celu realizacji większych transakcji zakładały spółki - societas argentariorum, ukazując w ten sposób poziom rozwoju instytucji bankierskich w prawie rzymskim („Spółki te wiązały się więc z działalnością bankierów zwanych argentarii" [s. 196]). W swoich rozważaniach Autor zwraca także uwagę na system nadzoru nad bankierami, który stworzyli rzymianie. W sposób chronologiczny wskazuje kolejno na urzędy publiczne - edyla plebejskiego, edyla kuralnego oraz praefectus Urbi, odpowiadające za rzetelne i zgodne z prawem funkcjonowanie banków. $\mathrm{W}$ rozdziale trzecim, podobnie jak $\mathrm{w}$ drugim, omawiając formy prowadzenia działalności bankierskich, P. Niczyporuk zawsze odwołuje się do konkretnych podmiotów - bankierów. W ten sposób konsekwentnie poszerza materiał etymologiczny z rozdziału pierwszego. Ma to niewątpliwy wpływ na postrzeganie bankierów rzymskich, których działalność usadowiona była $\mathrm{w}$ odpowiedniej przestrzeni i formie. Ta druga ukazana została m.in. poprzez dokumenty będące poświadczeniem/dowodem okoliczności zawarcia operacji bankierskich („Wśród tych dokumentów sporządzanych przez bankierów największe znaczenie miały codex accepti et expensi oraz rationes [codex rationum]. Wiązało się to przede wszystkim $\mathrm{z}$ ich wykorzystaniem w ewentualnym sporze z klientem" [s. 196-197]).

Na uwagę zasługuje także strona redakcyjna publikacji. Pomijając niewielkie uchybienia (wskazane już w Spisie treści), na podkreślenie zasługuje sporządzenie streszczeń aż w trzech językach. Szczególnie chciałabym zwrócić uwagę na streszczenie w języku łacińskim.

Monografię Piotra Niczyporuka można zaliczyć do dzieł godnych polecenia. Książka napisana jest w sposób przejrzysty i stanowi znakomite kompendium wiedzy o bankowości. Autor niezwykle czytelnie przedstawia skomplikowane zagadnienia dotyczące bankierów i operacji bankierskich w starożytnym Rzymie. Dodatkowo uzupełnia i porządkuje współczesne wyobrażenie o prawie rzymskim.

Emilia Twarowska-Antczak

(Uniwersytet im. Adama Mickiewicza w Poznaniu) https://orcid.org/0000-0003-4917-8881 


\section{BIBLIOGRAFIA (REFERENCES)}

Niczyporuk P., Aukcyjna sprzedaż majątków z udziałem bankierów w starożytnym Rzymie, $\mathrm{w}$ : Z zagadnień prawa rolnego, cywilnego i samorzadu terytorialnego. Księga jubileuszowa profesora Stanistawa Prutisa, red. J. Bieluk, A. Doliwa, A. Malarewicz-Jakubów, T. Mróz, Białystok 2012, s. 596-605.

Niczyporuk P., Bankierzy publiczni w starożytnym Rzymie, „,Zeszyty Naukowe Uniwersytetu Rzeszowskiego. Seria Prawnicza" 2014, 82, Prawo 14, s. 145-161.

Niczyporuk P., Bankierzy publiczni w źródłach prawa rzymskiego, "Zeszyty Prawnicze” 2014, 14.1, s. 113-131.

Niczyporuk P., Bankierzy u Plauta, „Zeszyty Naukowe Uniwersytetu Rzeszowskiego, Seria Prawnicza" 2014, 82, Prawo 14, s. 162-173.

Niczyporuk P., Legaty na rzecz wdowy w prawie rzymskim, „Miscellanea Historico-Iuridica” 2003, 1, s. 9-35.

Niczyporuk P., Mensarii, Bankers Acting for Public and Private Benefit , "Studies in Logic, Grammar and Rhetoric" 2011, 24 (37), s. 105-115.

Niczyporuk P., Mensarii - kak bankiry, „Miscellanea Historico-Iuridica” 2012, 11, s. 29-40.

Niczyporuk P., Nasciturus - postuтиs: римская юридческая терминология, применяемая для определения зачатого младенияа, \{Nasciturus - postumus: rzymska terminologia stosowana wobec dziecka poczętego\}, „Ius Antiquum” 2004, 2, 14, s. 116-131.

Niczyporuk P., Określenia stosowane w źródłach prawa rzymskiego wobec dziecka poczętego, a jeszcze nieurodzonego, w: O prawie i jego dziejach ksiegi dwie, red. P. Fiedorczyk, M. Mikołajczyk, Białystok-Katowice 2010, Księga I, s. 81-92.

Niczyporuk P., Operacje wykonywane przez bankierów rzymskich (argentarii), „Krytyka Prawa" 2013, 5, s. 481-506.

Niczyporuk P., Powtórne małżństwo wdowy w okresie tempus lugendi w epoce archaicznej prawa rzymskiego, w: Honeste vivere, Ksiega pamiatkowa ku czci Profesora Władysława Bojarskiego, red. A. Sokala, E. Gajda, Toruń 2001, s. 139-149.

Niczyporuk P., Rozważania Wolfganga Waldsteina o dziecku poczętym, w: Interes prywatny a interes publiczny w prawie rzymskim, red. B. Sitka, K. Naumowicz, K. Zaworska, Olsztyn 2012, s. 217-229.

Niczyporuk P., Rzymskie regulacje prawne związane z ochrona dziecka poczętego, „Miscellanea Historico-Iuridica" 2009, 8, s. 27-40.

Niczyporuk P., Sankcje nałożone na wdowe nie przestrzegająca zakazu powtórnego mał̇̇énstwa w okresie tempus lugendi, w: Contra leges et bonos mores. Przestępstwa obyczajowe w starożytnej Grecji i Rzymie, red. H. Kowalski, M. Kuryłowicz, Lublin 2005, s. 263-273.

Niczyporuk P., Stwierdzenie ciaży (inspectio ventris) jako środek ochrony interesów dziecka poczętego w prawie rzymskim, „Miscellanea Historico-Iuridica” 2010, 9, s. 29-40.

Niczyporuk P., Tempus lugendi, w: Miscellanea Historico-Iuridica Bialostocensia, Białystok 1995, s. 35-45.

Niczyporuk P., Warunek pozostania we wdowieństwie w prawie rzymskim, w: Przez tysiaclecia: państwo - prawo - jednostka. Materiaty z ogólnopolskiej konferencji historyków prawa. Ustroń 17-20 września 2000 r., t. 3, red. A. Lityński, M. Mikołajczyk, s. 199-214.

Niczyporuk P., Żałoba w prawie rzymskim, w: Prawo a dzieje państwa i ustroju, Białystok 1996, s. 57-77.

Niczyporuk P., Talecka A., Aukcyjna sprzedaż majątków jako jedna z form działalności bankierskiej w starożytnym Rzymie, w: Pieniądz - kapitat - praca - wspólne dziedzictwo Europy. Białoruś - Litwa - Łotwa - Polska - Rosja - Stowacja - Ukraina. Materiaty z VIII Międzynarodowej Konferencji Numizmatycznej, red. K. Filipow, Warszawa 2008, s. 21-27. 
Niczyporuk P., Talecka A., Babiloński kupiec-bankier (tamkarum) a wojna, w: Pieniądz i wojna. Białoruś - Litwa - Łotwa - Polska - Słowacja - Ukraina. Materiały z VI Międzynarodowej Konferencji Numizmatycznej, red. K. Filipow, Warszawa 2004, s. 15-23.

Niczyporuk P., Talecka A., Bank jako instytucja zaufania publicznego, w: Ekonomiczne aspekty państwa demokratycznego, red. S. Oliwniak, Białystok 2007, s. 73-88.

Niczyporuk P., Talecka A., Bankowość Unii Europejskiej. Podstawowe zagadnienia, Białystok 2010.

Niczyporuk P., Talecka A., Bankowość. Podstawowe zagadnienia, Białystok 2011.

Niczyporuk P., Talecka A., Bankowość. System bankowy i usługi, Białystok 2004.

Niczyporuk P., Talecka A., Bankovskaya sistema i bankovskoe regulirovanie v Evropejskom Soyuze, Belostok 2010.

Niczyporuk P., Talecka A., Czynności bankowe w starożytnym Rzymie a wspótczesne polskie prawo bankowe, w: Pieniądz i banki - wspólnota dziejów (tezauryzacja, obieg pieniężny, bankowość) - wspólnota dziejów. Białoruś - Litwa - Łotwa - Polska - Słowacja - Ukraina. Materiały z V Międzynarodowej Konferencji Numizmatycznej, red. K. Filipow, Warszawa 2002, s. 17-26.

Niczyporuk P., Talecka A., Kredyt bankowy dla jednostek samorządu terytorialnego w świetle regulacji prawnych, w: Finansowanie gminnego samorzadu terytorialnego, red. D.A. Hałaburda, Białystok 2008, s. 137-153.

Niczyporuk P., Talecka A., Nummularii jako strażnicy jakości monety w starożytnym Rzymie, w: Psucie pieniadza w Europie Środkowo-Wschodniej od antyku po czasy wspótczesne. Białoruś - Litwa - Łotwa - Polska - Stowacja - Ukraina. Materiały z VII Międzynarodowej Konferencji Numizmatycznej, red. K. Filipow Warszawa 2006, s. 23-30.

Niczyporuk P., Talecka A., Nummularii, gosudarstvennye i chastnye bankiry v dreonem Rime, „Miscellanea Historico-Iuridica” 2013, 12, s. 57-74.

Niczyporuk P., Talecka A., Początki instytucji wspótczesnego prawa bankowego w starożytności, w: Podstawy materialne państwa. Zagadnienia prawno-historyczne, red. D. Bogacz, M. Tkaczuk, Szczecin 2006, s. 337-352.

Niczyporuk P., Talecka A., Prawne aspekty czasu trwania ciąży w starożytnym Rzymie, w: Kobieta-Etyka-Ekonomia, red. E. Ozorowski, R.Cz. Horodeński, Białystok 2009, s. 107-125.

Niczyporuk P., Talecka A., Rzymska antyczna bankowość wspólnym dziedzictwem Europy, w: Pieniadz - symbol - władza - wojna - wspólne dziedzictwo Europy, Białoruś - Estonia Litwa - Łotwa - Polska - Rosja - Rumunia - Stowacja - Ukraina. Studia i materiały, red. K. Filipow, Augustów-Warszawa 2010, s. 27-41.

Petrucci A., Profi li giuridici delle attività e dell'organizzazione delle banche romane, Torino 2002. Stownik łacińsko-polski, t. I-V, red. M. Plezia, Warszawa 2007.

Sondel J., Ze studiów nad rola i miejscem łaciny prawniczej w kulturze europejskiej, „Krakowskie Studia z Historii Państwa i Prawa" 2014, 7, 1, s. 69-91. 